\title{
ОРАЛЬНАЯ $\alpha$-ГАЛАКТОЗИДАЗА
} В КЛИНИЧЕСКОЙ ПРАКТИКЕ

И. Хлынов, доктор медицинских наук,

М. Чикунова, кандидат медицинских наук,

0. Хромцова, доктор медицинских наук

Уральский государственный медицинский университет,

Екатеринбург

E-mail: hlinov.doc@yandex.ru

DOI: 10.29296/25877305-2018-01-18

Оцениваются эфффективность и безопасность оральной $\alpha$-галактозидазы при метеоризме и вздутии живота.

Ключевые слова: гастроэнтерология, метеоризм, вздутие живота, оральная $\alpha$-галактозидаза.

алактозидазы (галактозидгалактогидролазы) - ферменты, относящиеся к классу гидролаз (подкласс гликозидаз), отщепляющие галактозу от различных субстратов - олигосахаридов, полисахаридов и гликоконъюгатов (например, гликолипидов, гликопротеидов). Галактозидазы широко распространены в природе и обнаружены у растений, грибов и бактерий, а также в лизосомах клеток и биологических жидкостях животных и человека.

Галактозидазы разделяются на 2 вида: $\alpha$ - и $\beta$-галактозидазы. $\beta$-Галактозидаза, или лактаза, осуществляет гидролиз лактозы. Нарушение синтеза этого фермента у человека является причиной непереносимости лактозы молока. Снижение активности или отсутствие лизосомальной $\alpha$-галактозидазы человека, обусловленное генетической аномалией, приводит к развитию болезни Фабри, при которой парентеральная форма $\alpha$-галактозидазы применяется как заместительная терапия [5]. Вместе с тем для клинической медицины важен такой факт, как наличие $\alpha$-галактозидазы только в секрете слюнных желез человека и полное ее отсутствие в секрете тонкой кишки при высокой активности в реакциях расщепления галактоолигосахаридов (в частности, рафинозы и стахиозы), широко представленных в традиционных продуктах питания человека $[14,17]$. Относительную $\alpha$-галактозидазную ферментную недостаточность пищеварительной системы при употреблении нутриентов с галактоолигосахаридами - можно обсуждать как физиологическое для человека состояние.

Рафиноза (раффиноза) - невосстанавливающий трисахарид, состоящий из остатков $\alpha$-D-глюкозы, $\beta$-D-фруктозы и $\alpha$-D-галактозы. При действии $\alpha$-галактозидазы на рафинозу происходит расщепление на галактозу и сахарозу. Встречается данный трисахарид в сахарной свекле; ему не присущ сладкий вкус. Важно (особенно для диетологии), что при хранении свеклы содержание рафинозы в ней возрастает. Стахиоза (маннеотетроза) - невосстанавливающий тетрасахарид, состоящий из 2 остатков $\alpha$-D-галактозы, $\alpha$-D-глюкозы и $\beta$-D-фруктозы. Стахиоза является одним из резервных углеводов, содержащихся в бобовых (фасоль, соя, горох, чечевица).

Среди продуктов, содержащих галактоолигосахариды, фасоль (белая, красная, коричневая), чечевица, салат, капуста 
(белая, красная, брюссельская, цветная, брокколи), кольраби, лук, чеснок, морковь, свекла, петрушка, мука и мучные изделия (особенно цельных семян зерновых), фисташки, семена кунжута, соя и соевые продукты (соевое молоко, тофу), виноград и др.

Важное значение в клинической медицине имеет изучение связи нарушения метаболизма у человека указанных продуктов с развитием газ-ассоциированных симптомов (вздутия живота, метеоризма и флатуленции). Перечисленные симптомы остаются актуальной проблемой клинической практики из-за широкой распространенности в популяции (6-31\%) и влияния на качество жизни пациентов [6, 15]. Кишечный газ человека включает 5 основных составляющих: азот $\left(\mathrm{N}_{2}\right)$, кислород $\left(\mathrm{O}_{2}\right)$, двуокись углерода $\left(\mathrm{CO}_{2}\right)$, водород $\left(\mathrm{H}_{2}\right)$ и метан $\left(\mathrm{CH}_{4}\right)$. Азот и кислород попадают в состав кишечного газа при заглатывании воздуха; $\mathrm{CO}_{2}, \mathrm{H}_{2}$, $\mathrm{CH}_{4}$ образуются в результате бактериальной ферментации непоглощаемых диетических субстратов, в том числе олигосахаридов. Использование водородного дыхательного теста позволяет объективно изучать определенные реакции метаболизма кишечных газов.

Олигосахаридный метеоризм и вздутие живота связаны с устойчивостью олигосахаридов с 1- или 6-галактозной связью к гидролазам тонкой кишки человека и их последующей бактериальной ферментацией микрофлорой кишечника, что приводит к усилению процессов брожения в кишечнике, повышению продукции газов и развитию внутрикишечного вздутия $[2,7]$.

Современные исследования позволили выявить, помимо олигосахаридной мальабсорбции, разнообразный и широкий спектр патофизиологических процессов при метеоризме: нарушение обмена кишечных газов в тонкой кишке, особенности клиренса газов в проксимальных отделах ободочной кишки, психологические факторы, взаимодействие жидкостных сред и газов, увеличение поясничного лордоза, слабость мускулатуры брюшной стенки, расстройство сенсорной и моторной функций желудочно-кишечного тракта, синдром избыточного бактериального роста, изменение микрофлоры кишечника и непереносимость ряда нутриентов $[3,4,10,12$, 13, 16-18].

Метеоризм, связанный с непереносимостью нутриентов, требует от врача проведения дифференциации между олигосахаридзависимым метеоризмом и широким спектром других заболеваний и патологических состояний: лактазной недостаточностью, целиакией, непереносимостью фруктозы, полиолов (в частности, сорбитола), глютена (без целиакии). Основным доказательством алиментарной зависимости газ-ассоциированных симптомов является установление их причинно-следственной связи с приемом конкретных пищевых продуктов, в чем помогает ведение дневника питания.

Интерес к выделению галактоолигосахаридзависимого метеоризма и вздутия живота носит не только теоретический характер, но также имеет важный практический смысл. В настоящее время у врача появилась возможность выбора при указанном состоянии пациента: назначение элиминационной диеты, что нарушает принципы «рационального питания», или применение ферментозаместительной терапии оральной $\alpha$-галактозидазы, которая в Российской Федерации зарегистрирована под торговым названием Орликс ${ }^{\circledR}-$ фермент, расщепляющий 1- или 6-галактозные связи в олигосахаридах и тем самым предотвращающий процессы, лежащие в основе избыточной продукции кишечных газов и газассоциированных симптомов. Процесс получения данного фермента такой же, как человеческого инсулина, и включает культивирование бактерий Escherichia coli с геном, отвечающим за выработку $\alpha$-галактозидазы [1].

Оральную $\alpha$-галактозидазу (Орликс ${ }^{\circledR}$ ) принимают с первыми порциями пищи, содержащей галактоолигосахариды. Оптимальной считается дозировка 5 мг (1 таблетка) на перекусы, 10 мг (2 таблетки) - на основные приемы пищи и 15 мг (3 таблетки) - при обильном употреблении соответствующих продуктов [1].

Эффективность и безопасность оральной $\alpha$-галактозидазы при газ-ассоциированных симптомах изучена в ряде клинических исследований. Так, ранее в одном из исследований (двойном слепом перекрестном) T. Ganiats и соавт. (1994) было изучено влияние $\alpha$-галактозидазы на метеоризм и другие желудочно-кишечные симптомы у пациентов с непереносимостью олигосахаридов, разделенных на 2 группы: в 1-й группе завтрак, обогащенный олигосахаридами, сочетался с пероральным приемом $\alpha$-галактозидазы, во 2-й - с плацебо. В течение 1 нед на протяжении 6 ч после приема пищи определяли наличие, частоту и степень выраженности метеоризма и других симптомов. Отмечено снижение частоты метеоризма при дополнительном приеме $\alpha$-галактозидазы. Статистически значимая разница между группами выявлена уже через 5 ч после пробного завтрака $(\mathrm{p}=0,04)$.

В рандомизированном двойном слепом плацебоконтролируемом исследовании M. Di Stefano и соавт. [8] у добровольцев, принимавших пробный завтрак (420 г вареных бобов), оценивали по визуальной аналоговой шкале (ВАШ) в течение 8 ч выраженность метеоризма, вздутия живота, абдоминальной боли, дискомфорта и диареи. Исследование сопровождалось проведением 8-часового дыхательного водородного теста. Участники исследования в случайном порядке принимали 3 дня плацебо или $\alpha$-галактозидазу в дозе 300 GalU или 1200 GalU (GalU - галактозидные единицы; $1 \mathrm{GalU}$ - количество фермента, высвобождающего 1 мкмоль галактозы от субстрата за 1 мин). Результаты исследования показали, что прием $1200 \mathrm{GalU} \alpha$-галактозидазы сопровождается значительным (в 1,8 раза) уменьшением экскреции водорода по сравнению с плацебо $(\mathrm{p}<0,02)$, вместе с тем прием $300 \mathrm{GalU} \alpha$-галактозидазы достоверно не влиял на показатели водородного дыхательного теста по сравнению с плацебо $(\mathrm{p}>0,05)$. Число эпизодов метеоризма при приеме $1200 \mathrm{GalU}$ $\alpha$-галактозидазы было в 3 раза меньше, чем при применении плацебо ( $<0,01)$. Прием $300 \mathrm{GalU} \alpha$-галактозидазы также снижал количество эпизодов метеоризма по сравнению с плацебо, но статистически недостоверно ( $>>0,05)$. Нежелательные явления в процессе применения $\alpha$-галактозидазы не зарегистрированы [8].

В рандомизированном исследовании М. Hillila и соавт. [11] оценивали эффективность и переносимость $\alpha$-галактозидазы у 125 пациентов с синдромом раздраженного кишечника и вздутием живота. Одна группа пациентов принимала $\alpha$-галактозидазу, другая - плацебо. Длительность наблюдения составила 16 нед. Динамику отслеживали путем оценки симптомов заболевания по шкале IBS-Symptom Severity Score (ВАШ вздутия живота и метеоризма) в начале исследования, в период 12-недельной терапии и через 4 нед после ее окончания. По показателям указанной шкалы отмечено выраженное снижение вздутия живота к 12-й неделе на 12,2 балла (95\% доверительный интервал - ДИ - 4,6-19,8) в группе получавших $\alpha$-галактозидазу; для сравнения: в группе плацебо - уменьшение на 4,6 балла (95\% ДИ 3,0-12,3). Различий других показателей в группах не было. Важно отметить, что в данном 

исследовании область применения $\alpha$-галактозидазы не соответствовала зарегистрированной в Российской Федерации (предотвращение вздутия живота, вызванного приемом продуктов, вызывающих метеоризм).

В рандомизированном двойном слепом плацебоконтролируемом исследовании авторы [9] изучали эффективность и переносимость $\alpha$-галактозидазы у детей с заболеваниями, ассоциированными с метеоризмом. Одна группа $(\mathrm{n}=25)$ получала плацебо, другая $(\mathrm{n}=27)$ - таблетки или раствор (в зависимости от массы тела) $\alpha$-галактозидазы в течение 2 нед. Общее состояние, газ-ассоциированные симптомы (вздутие живота, метеоризм и боль в животе) фиксировались родителями и (или) пациентами 3 раза в день (утром - с 7 до 8 ч, днем - с 14 до 15 ч и вечером - с 18 до 19 ч) в течение всего периода лечения с использованием ВАШ Faces Pain ScaleRevised (FPS-R). Вздутие и метеоризм оценивали в баллах от 0 до 5 в соответствии с интенсивностью и частотой эпизодов в ежедневном дневнике. Интенсивность симптома $>4$ баллов расценивали как тяжелую. Первичной конечной точкой было уменьшение показателей FPS-R в конце лечения по сравнению с базовым уровнем, вторичными конечными точками снижение доли пациентов с соответствующими симптомами. Показатель FPS-R снизился больше в группе принимавших $\alpha$-галактозидазу (с 2,8 $\pm 1,8$ до 2,0 $\pm 1,7$ балла), чем в группе плацебо (с $2,3 \pm 0,9$ до $2,1 \pm 1,1$ балла); различия статистически значимы ( $\mathrm{p}=0,023)$. Число дней с тяжелым вздутием живота было значительно меньше в группе получавших $\alpha$-галактозидазу, чем плацебо (соответственно $3,4 \pm 3,6$ и 5,4 $\pm 3,4$ дня; $\mathrm{p}=0,037$ ). На фоне применения $\alpha$-галактозидазы достоверно сократилась доля пациентов с выраженностью метеоризма $>2$ баллов (с 59 до 19\%; p=0,024), в то время как в группе плацебо показатель не изменился (до и после лечения $-48 \%$ ). Не наблюдалось изменений в повседневной частоте стула, а также эпизодов спастической абдоминальной боли после лечения $\alpha$-галактозидазой и плацебо. Побочные эффекты при применении $\alpha$-галактозидазы в процессе исследования не зарегистрированы.

Анализ представленных данных в соответствии с принципами доказательной медицины позволяет говорить о положительном влиянии оральной $\alpha$-галактозидазы на метеоризм и вздутие живота при непереносимости галактоолигосахаридов. Объективным аргументом эффективности оральной $\alpha$-галактозидазы являются результаты дыхательного водородного теста в ходе клинического эксперимента, подтверждающие дозозависимое влияние оральной $\alpha$-галактозидазы на изучаемые симптомы.

В клинических исследованиях установлена безопасность рассматриваемой ферментозаместительной терапии при галактоолигосахаридзависимом метеоризме и вздутии живота. Применение оральной $\alpha$-галактозидазы при функциональных заболеваниях кишечника (например, синдром раздраженного кишечника) требует дальнейшего изучения.

В заключение важно отметить, что современные алгоритмы диагностики пациентов с газ-ассоциированными симптомами должны включать скрининг (в том числе путем ведения пищевого дневника) на непереносимость ряда нутриентов, из которых особое значение имеют галактоолигосахариды. Доказанные эффективность и безопасность при- менения оральной $\alpha$-галактозидазы в рандомизированных плацебоконтролируемых исследованиях расширяют терапевтические возможности лечения пациентов с метеоризмом и вздутием живота. Ферментозаместительная терапия оральной $\alpha$-галактозидазой (Орликс $\left.{ }^{\circledR}\right)$ позволяет больным придерживаться принципов рационального питания, не прибегая к элиминационной диете.

\section{Литература}

1. Аннотация к БАД Орликс: свидетельство о государственной регистрации RU.77.99.88.003.Е.007871.07.15 от 20.07.2015.

2. Ивашкин В.Т., Драпкина О.М. Пропедевтика внутренних болезней. Гастроэнтерология: учеб. пособие / М.: ГЭОТАР-Медиа, 2012; 160 с.

3. Accarino A., Perez F., Azpiroz F. et al. Abdominal distention results from caudo-ventral redistribution of contents // Gastroenterology. - 2009; 136: 1544-51.

4. Azpiroz F., Malagelada J. Abdominal bloating // Gastroenterology. - 2005; 129: 1060-78.

5. Bengtsson B., Johansson J., Hollak C. et. al. Enzyme replacement in Anderson-Fabry disease // Lancet. - 2003; 361: 269-356.

6. Chang L., Lee 0., Naliboff B. et al. Sensation of bloating and visible abdominal distension in patients with irritable bowel syndrome // Am. J. Gastroenterol. - 2001; 96: 3341-7.

7. Chumpitazi B., Shulman R. Dietary Carbohydrates and Childhood Functional Abdominal Pain // Ann. Nutr. Metab. - 2016; 68 (I): 8-17.

8. Di Stefano M., Miceli E., Gotti S. et al. The Effect of Oral $\alpha$-Galactosidase on Intestinal Gas Production and Gas Related Symptoms // Dig. Dis. Sci. - 2007; 52 (1): 78-83.

9. Giovanni Di Nardo, Salvatore Oliva, Federica Ferrari et al. Efficacy and tolerability of alpha-galactosidase in treating gas-related symptoms in children. A randomized, double-blind, plactbo-controlled trial // BMC Gastroenterology. 2013; $13: 142$.

10. Hernando-Harder A., Serra J., Azpiroz F. et al. Colonic responses to gas loads in subgroups of patients with abdominal bloating // Am. J. Gastroenterol. 2010; 10: 876-82

11. Hillila M., Fakkila M., Sipponen T. et al. Does oral alpha-galactosidase relieve irritable bowel symptoms? // Scand. J. Gastroenterol. - 2016; 51 (1): $16-21$.

12. Houghton L., Whorwell P. Towards a better understanding of abdominal bloating and distension in functional gastrointestinal disorders // Neurogastroenterol. Motil. - 2005; 17: 500-11.

13. Lin H. Small intestinal bacterial overgrowth: a framework for understanding irritable bowel syndrome // JAMA. - 2004; 292: 852-8.

14. Oh J., Lee J., Park H. et al. Alpha-Galactosidase activity in human saliva // Arch. Oral Biol. - 2008; 53 (9): 842-8.

15. Sandler R., Stewart W., Liberman J. et al. Abdominal pain, bloating, and diarrhea in the United States: prevalence and impact // Dig. Dis. Sci. - 2000; 45: 1166-71.

16. Serra J., Azpiroz F., Malagelada J. Impaired transit and tolerance of intestinal gas in the irritable bowel syndrome // Gut. - 2001; 48: 14-9.

17. Viana P., deRezende S., Falkoski D. et al. Hydrolysis of oligosaccharides in soybean products by Debaryomyces hansenii UFV1 $\alpha$-galactosidases // Food Chemistry. - 2007; 103 (2): 331-7.

18. Zar S., Benson M., Kumar D. Review article: bloating in functional bowel disorders // Aliment. Pharmacol. Ther. - 2002; 16: 1867-76.

\section{ORAL $\alpha$-GALACTOSIDASE IN CLINICAL PRACTICE}

I. Khlynov, MD; M. Chikunova, Candidate of Medical Sciences, O. Khromtsova, MD Ural State Medical University, Yekaterinburg

The paper evaluates the efficacy and safety of oral $\alpha$-galactosidase for flatulence and bloating.

Key words: gastroenterology, flatulence, bloating, oral $\alpha$-galactosidase. 